\title{
DATING ARCHAEOLOGICAL CULTURES BY THEIR MOATS? A CASE STUDY FROM THE EARLY BRONZE AGE SETTLEMENT FIDVÁR NEAR VRÁBLE, SW SLOVAKIA
}

\author{
Frank Schlütz $^{1 *} \cdot$ Felix Bittmann ${ }^{1}$ \\ ${ }^{1}$ Lower Saxony Institute for Historical Coastal Research, Viktoriastr. 26/28, 26382 Wilhelmshaven, Germany.
}

\begin{abstract}
This article uses age-depth models based on 29 accelerator mass spectrometry (AMS) dates from charred plant macroremains (seeds, chaff), wood charcoal, and snail shells found in two moats from the settlement Fidvár near Vráble (SW Slovakia) to improve the absolute chronology of the Early Bronze Age in central Europe. The charred macroremains were taxonomically identified to species or genus level and the lifespan of the objects and the archaeological context were considered carefully. The selected snail shells were identified to provide reliable age information. This study demonstrates that under certain conditions, ditch archives can be well suited to contribute to archaeological chronologies. For the first time, the transition from the Hatvan to the Únětice period is dated absolutely.
\end{abstract}

KEYWORDS: ditches, age models, archaeobotany, central Europe, Eneolithic, Early Bronze Age.

\section{INTRODUCTION}

The Early Bronze Age in south-central Europe started at the end of the 3rd millennium BC. Due to the growing demand for the new material bronze, trading increased including long-distance exchange (i.e. Baltic amber) and settlement activities along the ore-rich Carpathian Mountains intensified (Kienlin 2010, 2015). Fidvár, near Vráble in SW Slovakia, was in the center of one of the hotspots of metal exchange and communication at that time (Ducke and Rassmann 2010; Gauss et al. 2013).

Chronological systems in literature can differ noticeably and the available absolute dates are still limited, while regional comparisons are complicated by pronounced local developments (Kienlin 2010; Marková and Ilon 2013; Roberts et al. 2013). From the western foreland of the Carpathian Mountains of Slovakia, for example, the Únětice, Nitra, and Mad'arovce cultures are known, while the Hatvan, Füzesabony, and Otomani cultures occupied the central and eastern parts in the course of the Early Bronze Age. The Makó-Kosihy-Čaka complex represents the end of the prevailing Eneolithic (Buchvaldek et al. 2007; Bátora et al. 2008).

While the Unětice culture represents the Early Bronze Age in an area reaching from eastern Germany through Austria and Czechia into Slovakia, the Hatvan culture was centered in the Carpathian Basin at the northern Tisza River (Buchvaldek et al. 2007; Kienlin 2010). Besides its pottery style, the Hatvan culture is characterized by the beginnings of Bronze Age tell settlements, while the typical Únětice settlements were at ground level (Kienlin 2010). In southwest Slovakia, the southeast expanding Únětice culture occupied some of the northwesternmost Hatvan settlements and was followed by the Mad'arovce culture (Bátora et al. 2012). The disappearance of the Mad'arovce culture marks the end of the Early Bronze Age and was a gradual extinction, leaving behind in the settlements not many bronze or golden artifacts (Bátora 2009; Marková and Ilon 2013; Jelínek 2015; Vavák 2015).

In contrast to the neighboring regions, there are few absolute dates for the Early Bronze Age of Slovakia, and even these might be methodologically problematic (Forenbaher 1993; Peška 2012). The existing absolute chronologies are largely based on series of collagen accelerator mass spectrometry (AMS) dates on human bones from cemeteries (Bátora 2000; Görsdorf 2000; Bátora et al. 2008) or animal bones from cultural layers (Görsdorf et al. 2004). Uncertainties with bones including the extraction of collagen can possibly lead to deviations between different laboratories of some hundreds of years for the same archaeological period (Peška 2012).

\footnotetext{
*Corresponding author. Email: schluetz@nihk.de.
} 
In addition, clam shells and fish bones as found at Fidvàr (unpublished data) and other Early Bronze Age sites (Hlavatá 2015) raise the question as to the extent of a reservoir effect (Sayle et al. 2014; Shishlina et al. 2014). For the transition from the Hatvan to the Únětice culture observed in SW Slovakia, no absolute age control exists (Bátora et al. 2008, 2012). To expand the data available and to verify the existing absolute chronologies, we aimed to provide additional dates and a wider spectrum of dated materials.

\section{SITE DESCRIPTION}

Fidvár, near Vráble in SW Slovakia (Figure 1), is one of the most important and best-known Early Bronze Age settlements in the Carpathian Basin (Kienlin 2012). It was fortified by three generations of moats (Bátora et al. 2012). Fidvár is one of the very rare sites where the tell-building Hatvan culture from the Tisza area was succeeded by the central European Únětice culture. The oldest, inner moat was created by the Hatvan people and refilled by anthropogenic-derived sediments of 4-5 m depth (Bátora et al. 2008). During the Únětice period, the settlement reached its greatest extension ( $\sim 12 \mathrm{ha}$ ) and a second ditch took over the fortification function. The youngest moat, located between the previous two, was built during the following Mad'arovce period

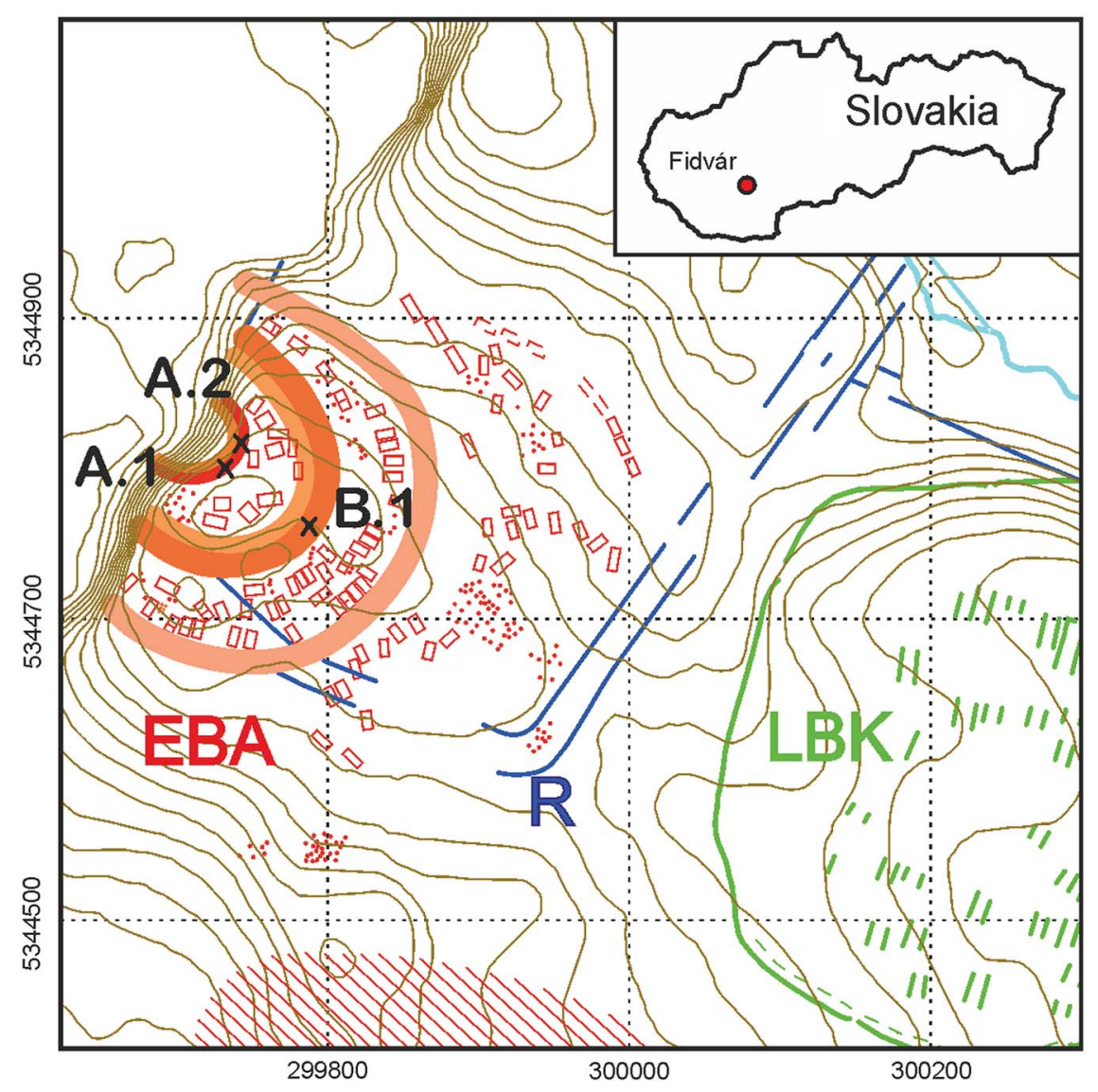

Figure 1 Archaeological structures at Fidvár reconstructed from geomagnetic surveys; EBA: Early Bronze age settlement, pits and cemetery; LBK, Neolithic ditch and houses; R, Roman march camp. WSG 1984 UTM 34 N, grid 200 m wide (Gauss et al. 2013; Nowaczinski et al. 2013). 
and was filled after the abandonment of the settlement by $7 \mathrm{~m}$ of sediments (Bátora et al. 2008; Nowaczinski et al. 2012). Some centuries before the rise of the fortified Early Bronze Age settlement, people of the Eneolithic Košihy Čaka culture inhabited the site (Točík 1986 in Bátora et al. 2008; Gauss et al. 2013).

The indirectly derived ages from archaeological artifacts for the Fidvár-Vráble site are somewhat vague (Bátora 2000; Bátora et al. 2008, 2012), not dating the Hatvan/Únětice transition, and seem to contradict the older ages of charcoals from the ditches (Nowaczinski et al. 2012; Nowaczinski 2014). In view of these uncertainties, we developed a new approach to derive a chronology based on taxonomically identified botanical and zoological macroremains from moats, a category of on-site archives that is still often underestimated.

\section{MATERIAL AND METHODS}

To cover the occupation phase and the following period, two percussion cores (A.1, A.2) from the oldest moat and one (B.1) from the youngest moat were selected for detailed microscopic analyses of pollen, archaeobotanical, and zoological remains (unpublished data). During the physical and chemical characterization of the cores, a total of nine obvious pieces of wood charcoal were directly sent for dating to the Curt Engelhorn Centre for Archaeometry in Mannheim (lab code MAMS) without any morphological or taxonomical analyses (Nowaczinski et al. 2012; Nowaczinski 2014). For our microscopic analyses, the cores were divided into natural stratigraphic layers and sublayers and each sample was wet sieved (smallest mesh diameter $0.25 \mathrm{~mm}$ ). After identification to the genus or species level, 18 botanical samples and 2 snail shells were dated at the Poznań Radiocarbon Laboratory (lab code Poz, Table 1). The shells were thoroughly cleaned mechanically, in an ultrasonic bath, and with diluted hydrochloric acid inside and out. For the principals of dating small snail shells, the reader is referred to Pigati et al. (2010, 2013). The age models were calculated using the free $\mathrm{R}$ package clam (Blaauw 2010) with the calibration curve IntCal13 (Reimer et al. 2013) and graphically reworked (Figure 2).

\section{RESULTS AND DISCUSSION}

A total of 29 samples were dated from the three cores A.1, A.2, and B.1 (Table 1). Apart from the nine wood charcoal samples, all remains were identified taxonomically. In contrast to the charcoal pieces, they are parts of plants or animals formed over short time periods of weeks (caryopses, seeds) to a few years (snail shells) and deposited shortly afterwards. All botanical remains were charred. To avoid mixing remains of potentially different ages, individual specimens were chosen for dating wherever feasible. This led in some cases to falling below the standard limit of the Poznan laboratory for carbon content of AMS samples of $0.4 \mathrm{mg}$ (http://www.radiocarbon.pl/).

\section{Charcoals}

While the taxonomic identities of the nine dated charcoal remains are uncertain (Nowaczinski 2014), not dated charcoals OR other charcoals from moat A, storage pits, and cultural layers were mostly identified as oak (Quercus) followed by ash (Fraxinus) and accompanied by charcoals of short-lived taxa like willow/poplar (Salix/Populus) and shrubs (Corylus, Buxus, Viburnum) (Schlütz and Bittmann 2015). Compared to the age models, a number of charcoals appear a few hundred years too old (Figure 2). This could be caused by dating inner parts of long-lived oak trees, the reuse of construction timber, or reworking. Charcoal ages that match with the models may originate from short-lived tree or shrub species, twigs, or the outer part of tree trunks.

In contrast to charcoals, all other dated botanical material (seeds, grains, spikelet forks) is of short-lived nature built over a few months by plants being annuals (wheat, goosefoot, hairy vetch) 
Table $1{ }^{14} \mathrm{C}$ dates from the moats.

\begin{tabular}{|c|c|c|c|c|c|c|c|c|}
\hline Structure & Core & No. & Material & $\begin{array}{l}\text { Depth } \\
(\mathrm{cm})\end{array}$ & $\begin{array}{l}\text { Lab code: } \\
{ }^{14} \mathrm{C} \text { age } \mathrm{BP}\end{array}$ & $\begin{array}{l}2 \sigma \mathrm{cal} \\
\mathrm{BC}(\%)\end{array}$ & $\begin{array}{l}\text { TOC } \\
\mathrm{mg} \mathrm{C}\end{array}$ & $\begin{array}{l}\text { Age vs. } \\
\text { model }\end{array}$ \\
\hline \multirow[t]{12}{*}{$\begin{array}{l}\text { Oldest } \\
\text { moat }\end{array}$} & \multirow[t]{12}{*}{ A. 1} & 1 & $\begin{array}{l}\text { Triticum mono./dico., } \\
\text { spikelet fork fragment }\end{array}$ & $140-170$ & Poz-65567: $3360 \pm 70$ & $\begin{array}{l}1876-1841(3.8) \\
1823-1795(2.4) \\
1782-1499(88.8)\end{array}$ & 0.3 & + \\
\hline & & 2 & Triticum sp., caryopsis & $140-170$ & Poz-65833: $3375 \pm 35$ & $\begin{array}{l}1752-1608(92.4) \\
1582-1560(2.6)\end{array}$ & - & + \\
\hline & & 3 & Charcoal & 194 & MAMS-14761: $3550 \pm 30$ & $\begin{array}{l}2006-2005(0.2) \\
1974-1861(66.0) \\
1853-1772(28.7)\end{array}$ & - & $>$ \\
\hline & & 4 & $\begin{array}{l}\text { Triticum monococcum, } \\
\text { spikelet fork fragment }\end{array}$ & $247-262$ & Poz-65834: $3510 \pm 90$ & $\begin{array}{l}2122-2093(1.7) \\
2042-1623(93.2)\end{array}$ & 0.14 & + \\
\hline & & 5 & $\begin{array}{l}\text { Triticum monococcum, } \\
\text { caryopsis }\end{array}$ & $262-286.5$ & Poz-66003: $3515 \pm 35$ & $1932-1748(95.0)$ & - & + \\
\hline & & 6 & Charcoal & 268 & MAMS-14762: $3685 \pm 30$ & $\begin{array}{l}2193-2178(2.5) \\
2143-2009(85.9) \\
2002-1977(6.6)\end{array}$ & - & $>$ \\
\hline & & 7 & $\begin{array}{l}\text { Chenopodium, seed } \\
\text { fragments }\end{array}$ & $327-342$ & $\begin{array}{l}\text { Poz-65835: } 119.2 \pm 0.55 \\
\text { pMC }\end{array}$ & $\begin{array}{l}\text { cal AD 1956-1965 (19.0) } \\
\text { cal AD 1980-1991 (76.4) }\end{array}$ & - & $<<$ \\
\hline & & 8 & $\begin{array}{l}\text { Triticum mono./dico., } \\
\text { spikelet fork fragment }\end{array}$ & $327-342$ & Poz-66004: $3530 \pm 60$ & $\begin{array}{l}2023-1737(92.3) \\
1715-1696(2.6)\end{array}$ & 0.3 & + \\
\hline & & 9 & Charcoal & 441 & MAMS-14763: $3610 \pm 30$ & $\begin{array}{l}2115-2099(2.8) \\
2037-1889(92.1)\end{array}$ & - & + \\
\hline & & 10 & Charcoal & 464 & MAMS-14764: $3695 \pm 30$ & $\begin{array}{l}2196-2170(6.2) \\
2147-2015(85.4) \\
1997-1980(3.4)\end{array}$ & - & $>$ \\
\hline & & 11 & $\begin{array}{l}\text { Triticum dicoccum, } \\
\text { caryopsis }\end{array}$ & $475-485$ & Poz-66005: $4050 \pm 35$ & $\begin{array}{l}2837-2815(5.7) \\
2672-2474(89.3)\end{array}$ & - & $>>$ \\
\hline & & 12 & Charcoal & 491 & MAMS-14765: $3660 \pm 30$ & 2135-1950 (95.0) & - & + \\
\hline
\end{tabular}




\begin{tabular}{|c|c|c|c|c|c|c|c|}
\hline \multirow[t]{8}{*}{ A. 2} & 13 & $\begin{array}{l}\text { Triticum dicoccum, } \\
\text { caryopsis }\end{array}$ & $220-239$ & Poz-65826: $3530 \pm 35$ & $1946-1753(95.0)$ & - & + \\
\hline & 14 & $\begin{array}{l}\text { Chenopodium, seed } \\
\text { fragments }\end{array}$ & $220-239$ & Poz-65825: $3790 \pm 70$ & $\begin{array}{l}2458-2112(83.6) \\
2103-2037(11.3)\end{array}$ & 0.16 & $>>$ \\
\hline & 15 & $\begin{array}{l}\text { Triticum dicoccum, } \\
\text { caryopsis }\end{array}$ & $243-253$ & Poz-65828: $3465 \pm 35$ & $\begin{array}{l}1883-1729(82.4) \\
1723-1692(12.4)\end{array}$ & - & + \\
\hline & 16 & $\begin{array}{l}\text { Chenopodium, seed } \\
\text { fragments }\end{array}$ & $243-253$ & Poz-65562: $3520 \pm 50$ & $\begin{array}{l}2007-2004(0.4) \\
1975-1737(92.2) \\
1714-1697(2.4)\end{array}$ & 0.4 & + \\
\hline & 17 & Charcoal & $251-252$ & MAMS-12967: $3590 \pm 20$ & $\begin{array}{l}2015-1997(8.6) \\
1980-1889(86.2)\end{array}$ & - & + \\
\hline & 18 & $\begin{array}{l}\text { Triticum monococcum, } \\
\text { caryopsis }\end{array}$ & $256-288$ & Poz-65829: $3670 \pm 60$ & $2203-1896(95.0)$ & 0.2 & + \\
\hline & 19 & Charcoal & $359-362$ & MAMS-12968: $4120 \pm 30$ & $\begin{array}{l}2865-2804(25.5) \\
2774-2770(0.7) \\
2764-2580(68.8)\end{array}$ & - & $>$ \\
\hline & 20 & Charcoal & 400 & MAMS-12969: $4210 \pm 30$ & $\begin{array}{l}2900-2851(35.5) \\
2813-2742(47.2) \\
2728-2694(12.1) \\
2682-2681(0.2)\end{array}$ & - & $>$ \\
\hline \multirow[t]{5}{*}{ B. 1} & 21 & Chondrula tridens, shell & $140-160$ & Poz-63626: $1675 \pm 30$ & $\begin{array}{l}\text { cal AD } 258-283(7.4) \\
\text { cal AD 322-424 (87.6) }\end{array}$ & - & + \\
\hline & 22 & Chondrula tridens, shell & $235-266$ & Poz-63627: $1965 \pm 30$ & $\begin{array}{l}41 \text { BC-AD } 85(93.9) \\
\text { AD } 110-115(1)\end{array}$ & - & + \\
\hline & 23 & Vicia hirsuta, single seed & $266-300$ & Poz-65830: $2145 \pm 35$ & $\begin{array}{l}355-287(25.4) \\
234-86(65.7) \\
80-55(3.8)\end{array}$ & - & + \\
\hline & 24 & $\begin{array}{l}\text { Sambucus ebulus, seed } \\
\text { fragments }\end{array}$ & $266-300$ & Poz-65563: $2235 \pm 30$ & $\begin{array}{l}387-343(22.5) \\
324-205(72.4)\end{array}$ & - & + \\
\hline & 25 & $\begin{array}{l}\text { Sambucus ebulus, single } \\
\text { seed }\end{array}$ & $330-350$ & Poz-65565: $3910 \pm 50$ & $\begin{array}{l}2563-2533(3.6) \\
2494-2277(87.2) \\
2252-2228(2.9) \\
2221-2210(1.2)\end{array}$ & 0.4 & $>>$ \\
\hline
\end{tabular}




\begin{tabular}{|c|c|c|c|c|c|c|c|c|}
\hline Structure & Core & No. & Material & $\begin{array}{l}\text { Depth } \\
(\mathrm{cm})\end{array}$ & $\begin{array}{l}\text { Lab code: } \\
{ }^{14} \mathrm{C} \text { age } \mathrm{BP}\end{array}$ & $\begin{array}{l}2 \sigma \mathrm{cal} \\
\mathrm{BC}(\%)\end{array}$ & $\begin{array}{l}\text { TOC } \\
\mathrm{mg} \mathrm{C}\end{array}$ & $\begin{array}{l}\text { Age vs. } \\
\text { model }\end{array}$ \\
\hline & & 26 & $\begin{array}{l}\text { Sambucus ebulus, single } \\
\text { seed }\end{array}$ & $570-600$ & Poz-65566: $3880 \pm 50$ & $\begin{array}{l}2472-2263(83.6) \\
2260-2206(11.3)\end{array}$ & 0.4 & $>>$ \\
\hline & & 27 & $\begin{array}{l}\text { Triticum dicoccum, } \\
\text { caryopsis }\end{array}$ & $570-600$ & Poz-65831: $3450 \pm 35$ & $1881-1684(95.0)$ & - & $>>$ \\
\hline & & 28 & Charcoal & 619 & MAMS-15362: $5230 \pm 20$ & $\begin{array}{l}4218-4214(0.6) \\
4151-4135(2.7) \\
4057-3972(91.6)\end{array}$ & - & $>>$ \\
\hline & & 29 & Triticum sp., caryopsis & $640-660$ & Poz-65832: $3340 \pm 35$ & $\begin{array}{l}1733-1719(3.2) \\
1693-1529(91.8)\end{array}$ & - & + \\
\hline
\end{tabular}

*Post-bomb atmospheric NH1 curve (Hua et al. 2013). Plant and zoological remains: Chenopodium (Ch. album, white goosefoot, and Chenopodium spec.), Triticum (wheat), T. monococcum (Einkorn), T. dicoccum (Emmer), Sambucus ebulus (danewort), Vicia hirsuta (tiny vetch), and Chondrula tridens (three-tooth bulin snail). Dates except those marked with + are treated as outliers (Figures 2,3,4) and classified as too old $(>$ ) where the divergence with the model age does not exceed the lifespan of the dated remains (here, trees) and as much too old ( >>). Charcoal data from Nowaczinski et al. (2012, 2014) calibrated in clam (Blaauw 2010) with IntCal13 (Reimer et al. 2013). 


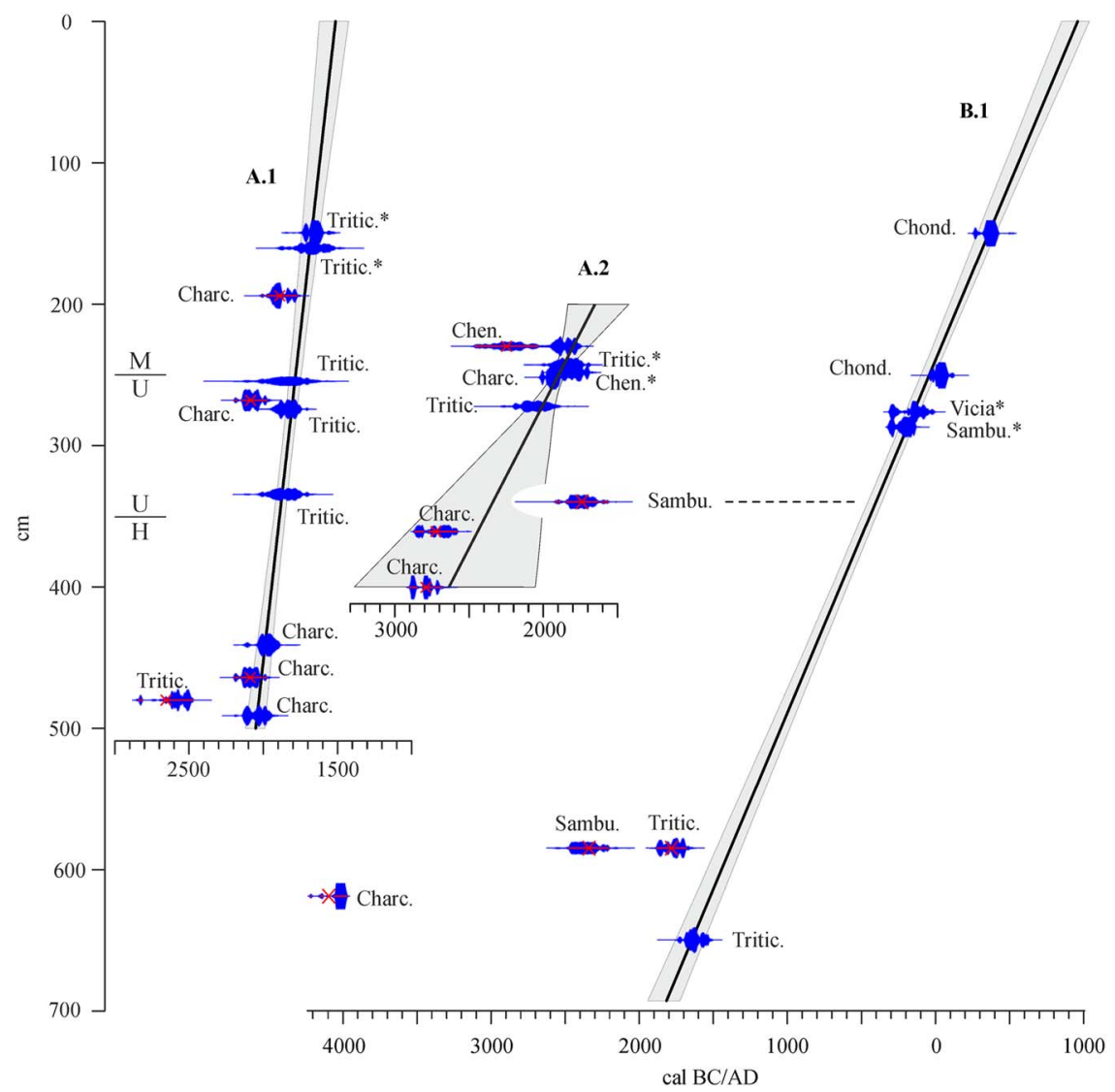

Figure 2 Age models of the ditches with the type of dated samples. Outliers are marked in red, with one recent date omitted. Transitions from Hatvan to Únětice (H/U, A.1) and Únětice to Mad'arovce (U/M, A.1, A.2) concluded from palynological and archaeobotanical analyses (Schlütz and Bittmann 2015). *Samples of overlapping depth graphically equalized; for acronyms see Table 1. All Sambucus (Sambu.) dates refer to core B.1. Gray zones mark the $95 \%$ confidential interval of age models, with red crossed samples not included. The upper part of the age model of core A. 2 was not plotted due to missing dates.

Table 2 Summary of sample age compared to model age or to the archaeological context for all types of material and in addition for those of low carbon content. For the explanation of symbols, refer to Table 1 .

\begin{tabular}{lccccc}
\hline Sample type & + & $>$ & $>>$ & $<<$ & $\Sigma$ \\
\hline Charcoal & 3 & 5 & 1 & & 9 \\
Triticum, caryopsis & 6 & - & 2 & - & 8 \\
Triticum, spikelet fork & 3 & - & - & - & 3 \\
Sambucus ebulus & 1 & - & 2 & - & 3 \\
Chenopodium & 1 & - & 1 & - & 3 \\
Vicia hirsuta & 1 & - & - & 1 & 1 \\
Chondrula tridens & 2 & - & 6 & - & 29 \\
Number of dates & 17 & 5 & 3 & & \\
Samples $\leq 0.4 \mathrm{mg} \mathrm{C}$ & 5 & - & &
\end{tabular}


or small herbs (danewort). Their carbon content therefore reflects most probably the atmospheric

${ }^{14} \mathrm{C}$ conditions shortly before the charring event.

\section{Wheat, Triticum}

In addition to eight wheat caryopses (grains), three fragments of spikelet forks (chaff remains) were also processed (Table 2). Especially the fragile spikelet forks that yielded only $0.2-0.3 \mathrm{mg}$ carbon each contributed significantly into building the age-depth models (Figure 3, Table 2). Wheat remains were restricted to the Early Bronze Age, except one (number 11), suggesting that wheat consumption occurred at the site much earlier, in the Eneolithic Košihy Čaka period.

\section{Danewort, Sambucus ebulus}

Three single seeds of danewort (Sambucus ebulus) were dated from core B.1. While the uppermost seed perfectly matches the age model, the two lower ones are both of the same age and much older than expected. Their old age points to fires possibly related to the Košihy Čaka culture known from the site before the Hatvan period (Bátora et al. 2008). The two seeds are separated by more than $2 \mathrm{~m}$ and were thus possibly independently incorporated into the ditch sediment with a time interval of more than about $1 \mathrm{ka}$. Nevertheless, bioturbation might be involved as well.

\section{Goosefoot, Chenopodium album}

Samples of Chenopodium consisting of more or less intact charred seeds of white goosefoot (Chenopodium album) and fragments, most probably also white goosefoot, were dated.

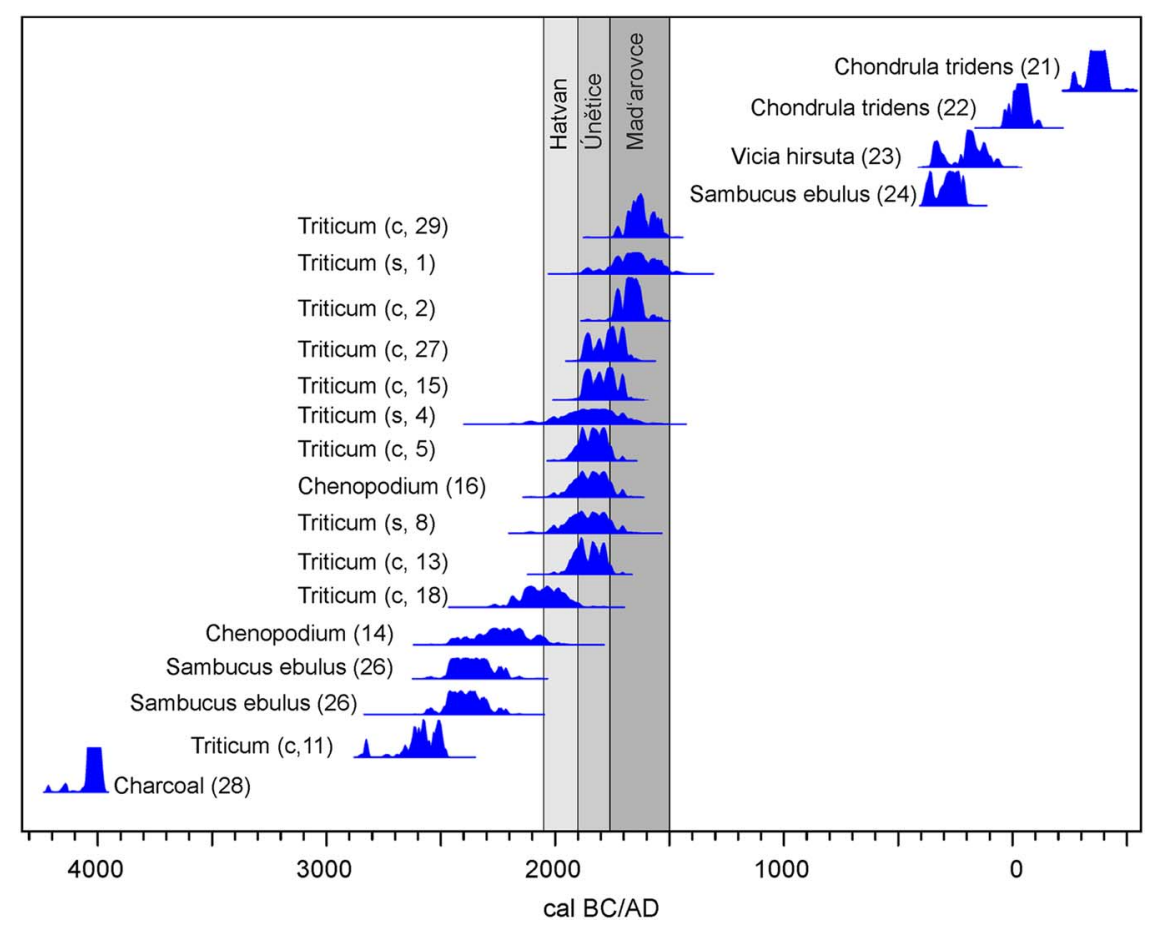

Figure 3 Results of all taxonomically identified remains and a single pre-Bronze Age charcoal sample. The beginning of Hatvan and Únětice period as concluded from core A.1. and end of Mad'arovce are in accordance with Bátora et al. (2012). Numbers in parentheses refer to Table 1 (c, caryopsis; s, spikelet fork fragment). 
Resulting from one recent date, the calibrated ages span over $4 \mathrm{ka}$. Goosefoot was, and still is, a very common weed at Fidvár. Most possibly the recent seeds were introduced into the material during fieldwork, as bioturbation down to more than $3 \mathrm{~m}$ depth seems unrealistic. Compared to all other remains, Chenopodiaceae samples gave the most unreliable results. This may relate to their high mechanical persistence, omnipresence, and minuteness, enabling any kind of relocation.

\section{Snail Shells, Chondrula tridens}

The three-tooth bulin snail (Chondrula tridens) forms high-spired shells of about 7-16 mm height (Welter-Schultes 2012) and prefers open xeric conditions, suggesting steppe-like conditions on the later moat slopes (Lisický 1991; Ložek 2012). Chondrula tridens feeds on dead plant material and deposits the eggs into the litter. As the species can move into soil cracks during dry periods (Boschi 2011), shells might be found some centimeters below the related ground level. Like other small terrestrial snails, the lifespan of Chondrula tridens will not exceed a few years. In general, snail shells appear less resistant to mechanical stress than charcoals, and are therefore most probably seldom reworked in archaeological contexts. Therefore, dating of complete and well-preserved shells may avoid problems of relocation. The two selected specimens $(8.5 \mathrm{~mm}, 7.0 \mathrm{~mm})$ were adults with well-developed apertural folds. They revealed sound ages without evidence of a carbon reservoir effect. Pigati et al. $(2010,2013)$ found that certain small snails only seldom have a reservoir effect, in contrast to larger snails. We believe that our results suggest Chondrula tridens snails also fall into this category of small snails. This probably offers significantly higher precision over archaeological finds of freshwater mollusks (Gulyás et al. 2010). Furthermore, the young ages mean that the shells did not originate from the Pleistocene loess in which the moats were dug (Ložek 1965). Other snails, like species of the genus Vallonia, are much more common in the moat sediments and even more fragile, but several shells would need to be combined to provide enough carbon for AMS dating. Nevertheless, they could be an appropriate key for further age controls.

Regarding Table 2, spikelet forks of Triticum seem to be the most reliable botanical dating material in our study. Due to their high fragility, spikelet forks when subject to any kind of reworking or redeposition possibly disintegrate instantly into units too small to be selected for dating. This kind of system inert preselection might also relate to a certain degree to cereal caryopses, as long as they are complete enough to be determined to at least genus level (Table 2, Triticum). For smaller fragments of caryopses, not dated in our study, a higher degree of mismatch due to redeposition might be expected. Seeds of Vicia hirsuta might fall into the same category as determinable caryopses, but further data are needed.

Charcoals and charred seeds of danewort and of goosefoot appear to be far less reliable. In this group, two-thirds of the dates turned out to be invalid. The resistant seeds of goosefoot and danewort are relatively frequent in our archaeobotanical spectra, but easily displaced by any kind of (bio-)turbation due to their small dimensions. Of short-living character, these seeds can show ${ }^{14} \mathrm{C}$ ages very close to the time of charring, but their susceptibility to reworking make them unsuitable for dating in archaeological contexts. Charcoals can be very stable as well and contain high amounts of carbon, explaining their frequent use in a wide range of geochronological applications (Bird 2007). In addition, charred beams and poles even disintegrated over several size orders through time by (recurrent) rework processes may still fulfill the quantitative requirements for AMS dating, resulting in ${ }^{14} \mathrm{C}$ ages (much) older than the archaeostratigraphical context. In addition, the so-called old-wood effect can reduce the chronostratigraphic usability of charcoal ages (Regev et al. 2012; Dong et al. 2014; 
Dreibrodt and Wiethold 2014). Especially in areas with long-living trees, like oaks in former SW Slovakia, the inbuilt age of the inner tree trunk can be several hundred years higher than the charring event (Gavin 2001). In landscapes with short-living arboreals, the resulting dating error might be only a few decades (Bruins and van der Plicht 1995). Due to the possible reuse of construction timber, the discrepancy between wood and fire age can be enhanced as well. Charred twigs or charcoals proven to be from shrubs like willow or hazel might provide acceptable results.

\section{DATING THE ARCHAEOLOGICAL PERIODS}

\section{Cores A.1 and A.2 from the Oldest Moat}

Cores A.1 and A.2 are from the oldest moat and consist of sediments filled into the ditches by humans. The age model of core A.1 dates the ditch base to about 2050 cal BC (Table 3). As deduced from the microscopic analyses (Schlütz and Bittmann 2015), the transition from the Hatvan to the Únětice culture is reflected in the sediments of core A.1 at about $3.5 \mathrm{~m}$ depth dating to about $1900 \mathrm{cal} \mathrm{BC} \mathrm{(Figure} \mathrm{2).} \mathrm{At} \mathrm{about} \mathrm{the} \mathrm{same} \mathrm{time,} 150 \mathrm{~km}$ to the east at Včelince, the pure Hatvan culture ended by the upcoming influence of the Otomani (Ottomány) culture (Görsdorf et al. 2004). The end of the Únětice period is marked by a loamy layer $(226-247 \mathrm{~cm})$ dating to about $1770 \mathrm{BC}$, which coincides with the end of the classical phase of the Unertice culture in its Bohemian heartland at Prague-Miškovice at around 1750 BC (Ernée et al. 2009).

The ditch was filled already approximately by the end of the Mad'arovce period at about $1500 \mathrm{cal}$ BC. Hence, the 5-m-deep sediments accumulated during just $500 \mathrm{yr}$, equating to an average rate of $10 \mathrm{~mm} / \mathrm{yr}$. Core A. 2 was taken several meters northeast of core A.1. No suitable material was recovered from its upper part. The density of dated material around $2.5 \mathrm{~m}$ is high, while the two charcoals from the base appear too old. Accordingly, the resulting age model is imprecise and not fully displayed in Figure 2. The transition from the Unnetice to the

Table 3 Results of the age models of core A.1 and B.1 at 50-cm intervals with cal BC in negative values.

\begin{tabular}{|c|c|c|c|c|c|c|}
\hline \multirow[b]{2}{*}{ Depth $(\mathrm{cm})$} & \multicolumn{3}{|l|}{ Core A.1 } & \multicolumn{3}{|l|}{ Core A. 2} \\
\hline & $\operatorname{Min} 95 \%$ & Best & $\operatorname{Max} 95 \%$ & Min $95 \%$ & Best & $\operatorname{Max} 95 \%$ \\
\hline 0 & -1622 & -1513 & -1425 & 851 & 959 & 1037 \\
\hline 50 & -1661 & -1567 & -1491 & 661 & 759 & 827 \\
\hline 100 & -1700 & -1621 & -1558 & 472 & 559 & 614 \\
\hline 150 & -1741 & -1674 & -1622 & 283 & 359 & 406 \\
\hline 200 & -1782 & -1728 & -1686 & 95 & 158 & 199 \\
\hline 250 & -1824 & -1782 & -1745 & -98 & -42 & -4 \\
\hline 300 & -1872 & -1836 & -1801 & -294 & -242 & -203 \\
\hline 350 & -1928 & -1889 & -1852 & -498 & -442 & -401 \\
\hline 400 & -1989 & -1943 & -1901 & -699 & -643 & -596 \\
\hline 450 & -2054 & -1997 & -1946 & -906 & -843 & -790 \\
\hline 500 & -2119 & -2051 & -1990 & -1118 & -1043 & -983 \\
\hline 550 & - & - & - & -1331 & -1244 & -1177 \\
\hline 600 & - & - & - & -1542 & -1444 & -1369 \\
\hline 650 & - & - & - & -1755 & -1644 & -1561 \\
\hline 690 & - & - & - & -1929 & -1804 & -1713 \\
\hline 693 & - & - & - & -1942 & -1816 & -1725 \\
\hline
\end{tabular}


Mad'arovce culture was less clear than in core A.1, but also situated around $2.5 \mathrm{~m}$ depth. Wheat and goosefoot from this particular section (Table 1, numbers 15, 16) gave ages in concordance with the age model of core A.1.

\section{Core B.1 from the Youngest Moat}

Charred remains are scarce and in some parts absent in core B.1. The age model suggests a refilling starting at $1800 \mathrm{BC}$. This early date is actually based on a single wheat caryopsis, which may have been reworked from cultural layers of the settlement. Archaeological reasoning suggests an installation of ditch B by the Mad'arovce people and therefore a start of the refilling about 3 centuries later with the end of the site occupation (Bátora et al. 2008; Falkenstein et al. 2008). Nevertheless, the refilling of this youngest ditch might have started like for the oldest one, shortly after the installation. A future use of snail shells for dating the base could be pioneering here. The deposition of the 7-m refill took roughly $2.5 \mathrm{ka}(\sim 2.8 \mathrm{~mm} / \mathrm{yr})$. The low rate is in sharp contrast to the anthropogenically influenced sedimentation rate of the oldest moat, which was about three times faster.

\section{Early Hatvan and Pre-Hatvan Dates}

The oldest ages of danewort and goosefoot (Figure 3) might be related to the Eneolithic Košihy Čaka or very early Hatvan activities that started about $150 \mathrm{~km}$ to the east at Včelince between 2200 and 2030 BC (Görsdorf et al. 2004). Goosefoot and danewort point to possibly human-made nitrogen-rich habitats already in this early occupation stage. The oldest wheat grain indicates cereal consumption in the Košihy Čaka period. The oldest charcoal (MAMS-15362) is of Neolithic origin and might relate to the nearby settlement located a few hundred meters east of the later Fidvár (Figure 1) (Furholt et al. 2014).

\section{CONCLUSION}

While archaeological excavations need time-consuming fieldwork, ditch cores can be taken rapidly by percussion drilling, but need intense sedimentological and microscopic analysis as well as thorough geochronological investigations. By using taxonomic identification of charred botanical remains and shells of small terrestrial snails, ambiguities related to carbonate reservoir effects (human bones, water mollusks, diet residuals) and collagen preparation can be minimized or prevented. Regarding the well-matching ages of cultural periods derived from bones (Görsdorf 2000; Görsdorf et al. 2004; Ernée et al. 2009) and botanical remains presented here, both dating approaches complement each other and provide mutual support. In addition, absolute ages of botanical remains offer direct evidence of former human activities like cereal cultivation and ecological conditions, such as the occurrence of nitrogen-rich soils and the steppe character of moats after the abandonment of the settlement. Cores of larger diameter or additional parallel cores could increase the amount of suitable remains and therefore enable the dating of smaller stratigraphic subdivisions. Snail shells can be an alternative when charred material is scarce and/or charred remains are not contemporaneous due to a lack of anthropogenic and natural fires and/or incorporation processes. The age-model-derived absolute chronology for all mentioned Early Bronze Age cultures is well within the age ranges given in the cited literature. The replacement of the Hatvan culture by the Únětice culture took place at around 1900 BC, which is the first absolute date for this important cultural transition. Its concomitance to the end of pure Hatvan culture may reflect simultaneous larger regional developments. The absolute chronostratigraphical framework presented here will also be helpful for regional and supraregional comparisons of future archaeobotanical and archaeological analyses (Bátora and Tóth 2014). In spite of the positive results presented, it should be kept in mind that moats like other ditches belong to a category of very complicated archives. Their utilization as chronological records might be successful only under certain circumstances. 


\section{ACKNOWLEDGMENTS}

The authors would like to thank the German Research Foundation (DFG) for funding this study (BI 783/5) as part of the bundle project "Holocene human-nature interaction at a geoecological key location - Geomorphological and sedimentological investigations at Vráble, Slovakia." We kindly thank our project partners from the Geographical Institute of Heidelberg, especially E Nowaczinski, for the generous release of the core material and fruitful discussions, as well as our archaeological partners from the RGK Frankfurt and from the Slovak Academy of Sciences for their support. Two anonymous reviewers helped to improve our manuscript considerably.

\section{REFERENCES}

Bátora J. 2000. On problems of absolute chronology of the Early Bronze Age in southwestern Slovakia. Geochronometria 19:33-6.

Bátora J. 2009. Metallurgy and Early Bronze Age fortified settlements in Slovakia. Slovenská Archeológia 57(2):195-219.

Bátora J, Tóth P. 2014. Settlement strategies in the Early Bronze Age in south-western Slovakia. In: Kienlin TL, Valde-Nowak P, Korczyńska MM, Cappenberg K, Ociepka J, editors. Settlement, Communication and Exchange around the Western Carpathians. Oxford: Archaeopress. p 325-40.

Bátora J, Eitel B, Falkenstein F, Rassmann K. 2008. Fidvár bei Vráble - Eine befestigte Zentralsiedlung der Frühbronzezeit in der Slowakei. In: Czebreszuk J, Kadrow S, Müller J, editors. Defensive Structures from Central Europe to the Aegean in the $3 \mathrm{rd}$ and 2nd Millenium BC. Poznań: Wydawnictwo Poznańskie. p 97-107.

Bátora J, Behrens A, Gresky J, Ivanova M, Rassmann K, Tóth P, Winkelmann K. 2012. The rise and decline of the Early Bronze Age settlement Fidvár near Vráble, Nitra. In: Kneisel J, Kirleis W, DalCorso M, Taylor N, Tiedtke V. Collapse or Continuity? Environment and Development of Bronze Age Human Landscapes. Bonn: Habelt. p 111-29.

Bird MI. 2007. Charcoal. In: Elias S, editor. Encyclopedia of Quaternary Science. Oxford: Elsevier. p 2950-8.

Blaauw M. 2010. Methods and code for 'classical' agemodelling of radiocarbon sequences. Quaternary Geochronology 5(5):512-8.

Boschi C. 2011. Die Schneckenfauna der Schweiz: Ein umfassendes Bild- und Bestimmungsbuch. Bern: Haupt.

Bruins HJ, van der Plicht J. 1995. Tell Es-Sultan (Jericho): radiocarbon results of short-lived cereal and multiyear charcoal samples from the end of the Middle Bronze Age. Radiocarbon 37(2):213-20.

Buchvaldek M, Kosnar L, Lippert A. 2007. Atlas zur Prähistorischen Archäologie Europas. Praehistorica 27. Prague: University of Karlova.

Dong G, Wang Z, Ren L, Motuzaite Matuzeviciute G, Wang H, Ren X, Chen F. 2014. A comparative study of ${ }^{14} \mathrm{C}$ dating on charcoal and charred seeds from Late Neolithic and Bronze Age sites in Gansu and Qinghai Provinces, NW China. Radiocarbon 56(1):157-63.
Dreibrodt S, Wiethold J. 2014. Lake Belau and its catchment (northern Germany). A key archive of environmental history in northern central Europe since the onset of agriculture. The Holocene 25(2):296-322.

Ducke B, Rassmann K. 2010. Modellierung und Interpretation der Kommunikationsräume des 3 . und frühen 2. Jahrtausends v. Chr. in Europa mittels Diversitätsgradienten. Archäologischer Anzeiger (2010, 1):239-61.

Ernée M, Müller J, Rassmann K. 2009. Ausgrabung des frühbronzezeitlichen Gräberfelds der Aunjetitzer Kultur von Prag-Miškovice: Vorläufige Auswertung und erste Ergebnisse der naturwissenschaftlichen Untersuchungen. ${ }^{14} \mathrm{C}$-Daten und Metallanalysen. Germania: Anzeiger der Römisch-Germanischen Komission des Deutschen Archäologischen Instituts 87(2):355-410.

Falkenstein F, Bátora J, Eitel B, Rassmann K. 2008. Archäologische Prospektionen auf einer befestigten Zentralsiedlung der Frühbronzezeit in der Slowakei. Mitteilungen der Berliner Gesellschaft für Anthropologie, Ethnologie und Urgeschichte 29:39-49.

Forenbaher S. 1993. Radiocarbon dates and absolute chronology of the central European Early Bronze Age. Antiquity 67(255):218-56.

Furholt M, Bátora J, Cheben I, Kroll H, Rassmann K, Tóth P. 2014. Vráble-Vel'ké Lehemby: eine Siedlungsgruppe der Linearkeramik in der Südwestslowakei. Vorbericht über die Untersuchungen der Jahre 2010 und 2012 und Deutungsansätze. Slovenská Archeológia 62(2):227-66.

Gauss RK, Bátora J, Nowaczinski E, Rassmann K, Schukraft G. 2013. The Early Bronze Age settlement of Fidvár, Vráble (Slovakia): reconstructing prehistoric settlement patterns using portable XRF. Journal of Archaeological Science 40(7):2942-60.

Gavin DG. 2001. Estimation of inbuilt age in radiocarbon ages of soil charcoal for fire history studies. Radiocarbon 43(1):27-44.

Görsdorf J. 2000. Interpretation der Datierungsergebnisse von Menschenknochen aus dem Gräberfeld Jelšovce. Geochronometria 19:37-40.

Görsdorf J, Marková K, Furmánek V. 2004. Some new ${ }^{14} \mathrm{C}$ data to the Bronze Age in the Slovakia. Geochronometria 23:79-91. 
Gulyás S, Sümegi P, Molnár M. 2010. New radiocarbon dates from the Late Neolithic tell settlement of Hódmezővásárhely-Gorzsa, SE Hungary. Radiocarbon 52(2-3):1458-64.

Hlavatá J. 2015. Environmental archaeology use archaeobotany. In: Hulínek D, editor. Archaeology on Three Continents 2006 - 2011. Bratislava: Slovak Archaeological and Historical Institute. p 111-9.

Hua Q, Barbetti M, Rakowski AZ. 2013. Atmospheric radiocarbon for the period 1950-2010. Radiocarbon 55(4):2059-72.

Jelínek P. 2015. A note on spiritual life of the Madarovce culture. In: Hulínek D, editor. Archaeology on Three Continents 2006 - 2011. Bratislava: Slovak Archaeological and Historical Institute. p 89-109.

Kienlin TL. 2010. Traditions and Transformations: Approaches to Eneolithic (Copper Age) and Bronze Age Metalworking and Society in Eastern Central Europe and the Carpathian Basin. BAR International Series 2184. Oxford: Archaeopress.

Kienlin TL. 2012. Patterns of change, or: perceptions deceived? Comments on the interpretation of Late Neolithic and Bronze Age tell settlement in the Carpathian Basin. In: Kienlin TL, Zimmermann A. Beyond Elites. Alternatives to Hierarchical Systems in Modelling Social Formations. International Conference at the Ruhr-Universität Bochum, Germany, October 22-24, 2009. Bonn: Habelt. p 251-310.

Kienlin TL. 2015. Bronze Age Tell Communities in Context - An Exploration into Culture, Society, and the Study of European Prehistory. Oxford: Archaeopress.

Lisický MJ. 1991. Mollusca slovenska. Bratislava: Veda, vydavatel'stvo Slovenskej akadémie vied.

Ložek V. 1965. Das Problem der Lößbildung und die Lößmollusken. Eiszeitalter und Gegenwart 16:61-75.

Ložek V. 2012. Molluscan and vertebrate successions from the Vel'ká Drienčanská Cave. Malacologica Bohemoslovaca 11:39-44.

Marková K, Ilon G. 2013. Slovakia and Hungary. In: Fokkens H, Harding A, editors. The Oxford Handbook of the European Bronze Age. Oxford: Oxford University Press. p 813-36.

Nowaczinski E. 2014. Multi-scale geomorphological and geoarchaeological investigations of a key site - the Early Bronze Age settlement of Fidár (Slovakia) [dissertation]. University of Heidelberg, Germany.

Nowaczinski E, Schukraft G, Hecht S, Rassmann K, Bubenzer O, Eitel B. 2012. A multimethodological approach for the investigation of archaeological ditches - exemplified by the Early Bronze Age settlement of Fidvár near Vráble (Slovakia). Archaeological Prospection 19(4):281-95.

Nowaczinski E, Schukraft G, Rassmann K, Hecht S, Texier F, Eitel B, Bubenzer O. 2013. Geophysicalgeochemical reconstruction of ancient population size - the Early Bronze Age settlement of Fidvár (Slovakia). Archaeological Prospection 20(4):267-83.
Peška J. 2012. Beispiele der absoluten Chronologie der Frühbronzezeit in Mähren und ihrer Verknüpfung mit der Ägäis. In: Kujovský R, Mitáš V. Václav Furmánek a doba bronzová. Nitra. p 297-314.

Pigati JS, Rech JA, Nekola JC. 2010. Radiocarbon dating of small terrestrial gastropod shells in North America. Quaternary Geochronology 5(5):519-32.

Pigati JS, McGeehin JP, Muhs DR, Bettis EA III. 2013. Radiocarbon dating late Quaternary loess deposits using small terrestrial gastropod shells. Quaternary Science Reviews 76:114-28.

Regev J, de Miroschedji P, Boaretto E. 2012. Early Bronze Age chronology: radiocarbon dates and chronological models from Tel Yarmuth (Israel). Radiocarbon 54(3-4):505-24.

Reimer PJ, Bard E, Bayliss A, Beck JW, Blackwell PG, Bronk Ramsey C, Buck CE, Cheng $\mathrm{H}$, Edwards RL, Friedrich M, Grootes PM, Guilderson TP, Haflidason H, Hajdas I, Hatté C, Heaton TJ, Hoffmann DL, Hogg AG, Hughen KA, Kaiser KF, Kromer B, Manning SW, Niu M, Reimer RW, Richards DA, Scott EM, Southon JR, Staff RA, Turney CSM, van der Plicht J. 2013. IntCal13 and Marine13 radiocarbon age calibration curves $0-50,000$ years cal BP. Radiocarbon 55(4):1869-87.

Roberts BW, Uckelmann M, Brandherm D. 2013. Old father time: the Bronze Age chronology of Western Europe. In: Fokkens H, Harding A, editors. The Oxford Handbook of the European Bronze Age. Oxford: Oxford University Press. p 17-46.

Sayle KL, Cook GT, Ascough PL, Gestsdóttir H, Hamilton WD, McGovern TH. 2014. Utilization of $\delta^{13} \mathrm{C}, \delta^{15} \mathrm{~N}$, and $\delta^{34} \mathrm{~S}$ analyses to understand ${ }^{14} \mathrm{C}$ dating anomalies within a Late Viking Age community in northeast Iceland. Radiocarbon 56(2):811-21.

Schlütz F, Bittmann F. 2015. Archäobotanische und pollenanalytische Untersuchungen zu Subsistenz und Umwelteinfluss der bronzezeitlichen Siedlung Fidvár bei Vráble (Slowakei). Siedlungs- und Küstenforschung im südlichen Nordseegebiet 38:271-85.

Shishlina N, Sevastyanov V, Zazovskaya E, van der Plicht J. 2014. Reservoir effect of archaeological samples from Steppe Bronze Age cultures in southern Russia. Radiocarbon 56(2):767-78.

Točík A. 1986. Opevnené sídlisko zo staršej doby bronzovej vo Vrábloch. Slovenská Archeológia 34(2):463-76.

Vavák J. 2015. The 2010 trial excavations of a fortified settlement at Budmerice. Preliminary report. In: Hulínek D, editor. Archaeology on Three Continents 2006 - 2011. Bratislava: Slovak Archaeological and Historical Institute. p 77-87.

Welter-Schultes FW. 2012. European Non-Marine Molluscs, a Guide for Species Identification: Bestimmungsbuch für europäische Land- und Süsswassermollusken. Göttingen: Planet Poster Editions. 